\title{
Reconstruction of the Hand Defects by Pedicled Abdominal Thin Skin Flaps
}

\author{
Ricardo Monreal ${ }^{1}$, Damian Gomez ${ }^{2}$, Giovanni Osinaga ${ }^{3}$, Paul I de la $\mathrm{Cruz}^{4}$ and Eilen Monreal ${ }^{5}$ \\ ${ }^{1}$ Centro Medico MEDEX, San Isidro-Lima, USA \\ ${ }^{2}$ Hospital Universitario Madrid Torrelodones, Torrelodones, Spain \\ ${ }^{3}$ Hospital Obrero No. 3, Caja Nacional de Salud, USA \\ ${ }^{4}$ Clinicas Maison de Sante, Chorrillos, USA \\ ${ }^{5}$ School of Medicine, Ricardo Palma University, USA
}

Submission: April 25, 2017; Published: May 04, 2017

*Corresponding author: Ricardo Monreal, Centro Medico MEDEX, Republica de Panama 3065 2do piso, San Isidro-Lima, Clinicas Maison de Sante, Ave Chorrillos 171, Chorrillos, Lima, Peru, USA, Email: rmonreal59@yahoo.es

Abstract

Purpose: To present a random-pattern flap technique using pedicle ultra-thin abdominal flap used in the reconstruction of soft tissue defects of the hand in an attempt to avoid the bulky abdominal flap, and minimizing the donor site morbidity of abdominal flap.

Patients and Methods: Between 2013 and 2016, six male patients with hand defects received reconstructive surgery. Hand defects were in the form of mutilating hand injuries that leave a "good" thumb. The flaps were elevated ultra-thin, keeping a very thin layer of fat that ensures the existence of the sub dermal plexus. All the flaps were divided after 15 days.

Results: All flaps gave a satisfactory coverage with excellent contouring, and did not require revision.

Conclusion: Ultra-thin abdominal flap is safe, easy to harvest, has no donor site morbidity, and does not require a secondary debulking surgery.

Keywords: Ultra thin abdominal flaps; Hand; Soft tissue reconstruction; Sub dermal vascular plexus

\section{Introduction}

Post traumatic skin defects of the hand and its reconstruction represent a challenging problem in order to restore function and good aesthetic appearance. Pedicled flaps from the abdomen have several disadvantages including patient discomfort, the need for flap division, increased hospital stay, secondary flap debulking, and joint stiffness [1,2]. In the current era of microsurgery, free flap reconstruction has become the method of choice in coverage of complex hand defects and its main indication is a lack of microsurgical expertise although the use of pedicled abdominal flaps continues to have a place in centers with microsurgical expertise [3-6]. In this study, pedicled ultrathin abdominal flap is used in the reconstruction of soft tissue defects of the hand in an attempt to avoid the bulky abdominal flap, and minimizing the donor site morbidity of the flap.

\section{Patients and Methods}

Between 2013 and 2016, six male patients with hand defects received reconstructive surgery. Hand defects were in the form of mutilating hand injuries that leave a "good" thumb, as shown in (Figures 1a \&1b). All patients were operated upon by general anesthesia and the wound and all necrotic o devitalized tissue (including skin, tendon, muscle, bone, etc.) were debrided. Measurement the dimension of the defects was taken (the size of defects was ranged from a minimum of $6 \times 10$ and a maximum of $10 \times 18$ centimeters). Dorsal defects are best covered using inferiorly based flaps, whereas volar defects are best covered by superiorly based flaps. Ultra-thin abdominal skin flap with a random pattern was raised at the level of sub dermis and a very thin layer of subcutaneous fat underneath the flap was kept 
(Figures $1 \mathrm{~b} \& 1 \mathrm{c}$ ). In setting of the flap with monofilament nylon sutures was performed (Figure 2a). The donor site is closed by direct suture (Figure 2b). The limb was kept in position with a bandage that does not make tension on the flap (Figure 2c). The pedicle flap was dressed after one-week postoperatively. All the flaps were divided after 15 days.
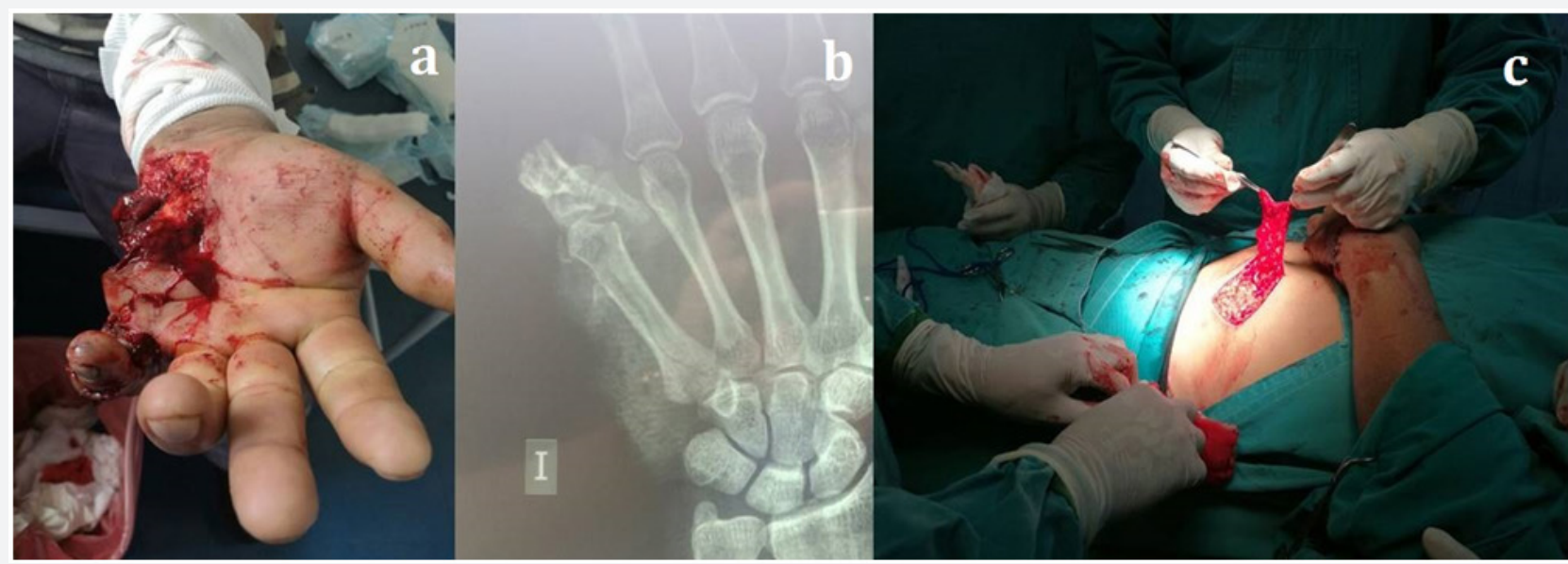

Figure 1: Use of an abdominal flap in a mutilating hand injury. Note the presentation of a good thumb.

a. The acute defect. The amputated finger was crushed and not replantable but the 5 th metacarpal was preserved

b. X-ray showing a remnant of the proximal phalange.

c. Elevation of ultra-thin abdominal flap.

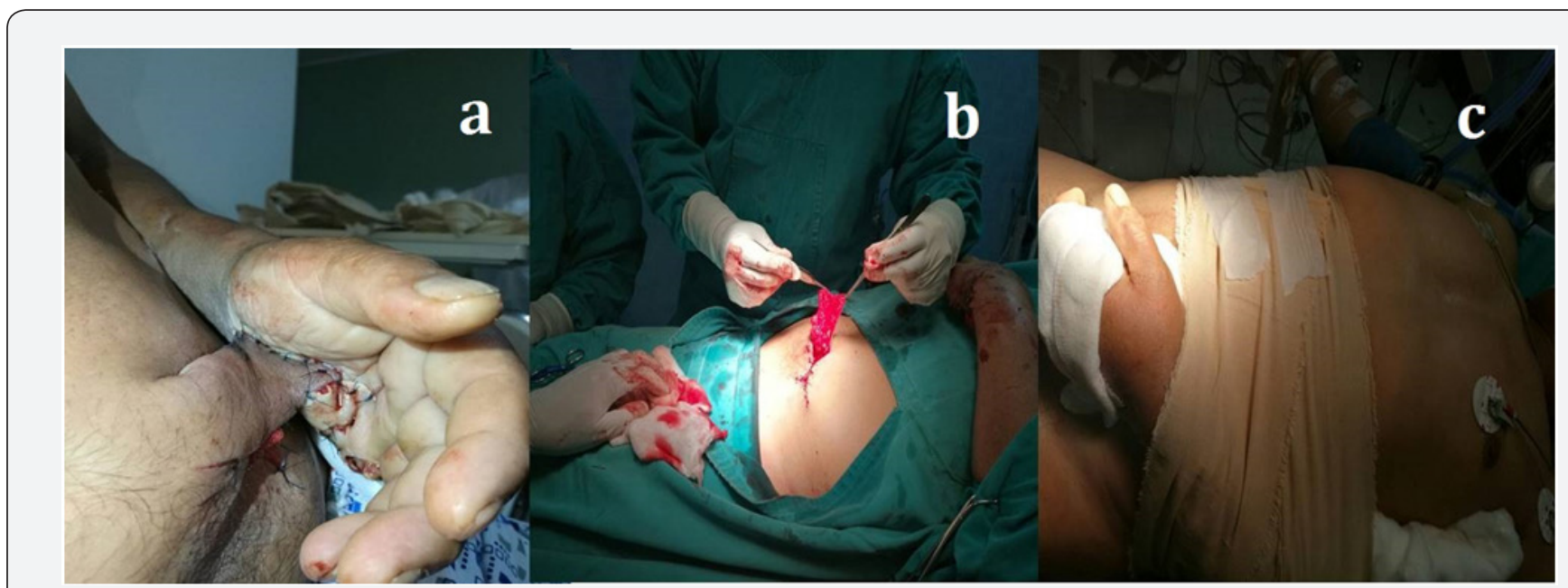

\section{Figure 2:}

a. Coverage of the hand by the abdominal flap, showing the favorable ratio of length to breadth.

b. Closure of the secondary defect of the abdominal flap by direct suture.

c. The limb was kept in position with a bandage.

\section{Results}

Soft tissue defects in the hand were reconstructed by ultra thin abdominal flap. All flaps gave a satisfactory coverage with excellent contouring, and did not require revision (Figure 3).

\section{Discussion}

Soft tissue reconstruction of the hand remains a challenge for reconstructive surgeons. Skin defects of the hand may be covered by local, distant, or free flaps, depending on the general condition of the patient and the local condition of the wound and donor site. Because of the special needs for the hand, three types of flaps have been mentioned:
a. The random pattern flap,
b. The axial pattern flap, and
c. The free flap.

A random pattern flap may be defined as a flap with a vascular pattern which lacks bias in any particular direction and 
which is subject to relatively strict limitations of length: breadth ratio. An axial pattern flap may be defined as one constructed around a preexisting, anatomically recognized arteriovenous system. It is independent of length: breadth ratio; its length is dictated by the territory of its axial artery.

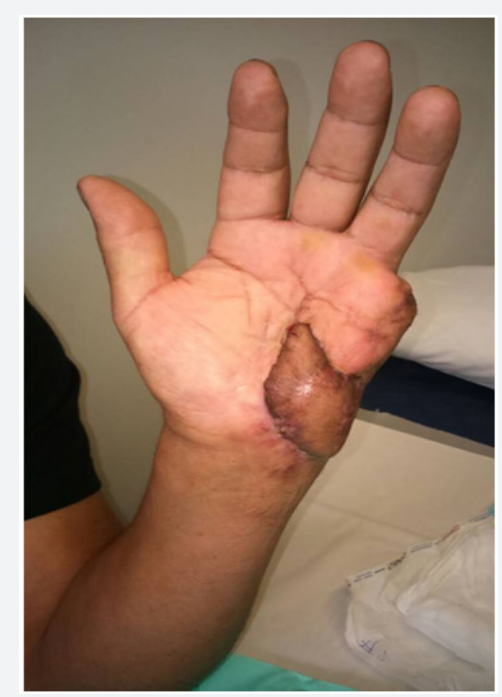

Figure 3: The flap completely survived. The flap has a good contour.

Free flap is an alternative option to reconstruct soft tissue defects of the hand but it is a time-consuming procedure, requires a more difficult technique and complicated postoperative care [7]. Complex hand defects in children aged less than 2 years, mutilating hand injuries, length preservation of multiple digital amputations, and multiple complex defects in the hand should be considered indications for pedicle abdominal flaps in the current era of microsurgery [8-11]. Two situations in which pedicle abdominal flaps may be preferred are degloving injuries of all fingers and mutilating hand injuries that leave a "good" thumb [12]. Random pattern abdominal flap was frequently used to cover traumatic defects involving the hand but bulkiness of the flap and two-stage procedure were the main disadvantages of abdominal flap. When designing abdominal flaps, considerations are made regarding the blood supply to the flap, patient comfort, and the site of the defect. Dorsal defects are best covered using inferiorly based flaps, whereas volar defects are best covered by superiorly based flaps [8]. Lin and his colleagues used the pedicle skin flaps of sub dermal vascular plexus for reconstruction of hand defects [13].

The thinning of flaps cannot be discussed without considering the work of Colson et al. [14] which it has been strangely neglected in the Anglo-American literature. They have found that surprisingly large flaps can survive apparently entirely on this plexus with virtually no subcutaneous. The main indication for using pedicled flaps is the lack of microsurgical expertise it uses continues to have a place in centers with microsurgical expertise [3]. Abdominal ultra-thin skin flaps could be an ideal choice for the repair of hand defects [15]. In the present study, all abdominal thin skin flaps survived, and did not require revision.

\section{Conclusion}

Ultra-thin abdominal flap is safe, easy to harvest, has no donor site morbidity, and does not require a secondary debulking surgery.

\section{Statement of Informed Consent}

All study participants provided informed written consent prior to study enrollment.

\section{Statement of Human Rights}

All procedures followed were in accordance with the Helsinki Declaration of 1975 , as revised in 2008. Informed consent was obtained from all patients for being included in the study.

\section{References}

1. Barillo DJ, Arabitg R, Cancio LC, Goodwin CW (2001) Distant pedicle flaps for soft tissue coverage of severely burned hands: An old idea revisited. Burns 27(6): 613-619.

2. OlaOlorun DA (2001) Abdominal fasciocutaneous flap for upper extremity wound coverage in the developing world: Indications and complications. Trop Doct 31(1): 45-46.

3. Goertz O, Kapalschinski N, Daigeler A, Hirsch T, Homann HH, et al. (2012) The effectiveness of pedicled groin flaps in the treatment of hand defects: results of 49 patients. J Hand Surg Am 37(10): 20882094.

4. Yilmaz S, Saydam M, Seven E, Ercocen AR (2005) Para-umbilical perforator based pedicled abdominal flap for extensive soft-tissue deficiencies of the forearm and hand. Ann Plast Surg 54(4): 365-368.

5. Gutwein LG, Merrel GA, Knox KR (2015) Paraumbilical perforator flap for soft tissue reconstruction of the forearm. J Hand Surg Am40(3): 586-592.

6. O'Shaughnessy KD, Rawlani V, Hijjawi JB, Dumanian GA (2010) Oblique pedicled para-umbilical perforator-based flap for reconstruction of complex proximal and mid-forearm defects: a report of two cases. J Hand Surg Am 35(7): 1105-1110.

7. Zhou LR, Li J, Wang W (2003) Microsurgical repair of skin-degloving injury of whole hand or foot. Zhongguo Xiu Fu Chong Jian Wai Ke Za Zhi 17(4): 321-323.

8. Al Qattan MM, Al-Qattan AM (2016) Defining the indications of pedicled groin and abdominal flaps in hand reconstruction in the current microsurgery era. J Hand Surg Am 41(9): 917-927.

9. Buja Z, Arifi H, Hoxha E (2013) Repair of degloving fingers with abdominal tunnelization flap. J Hand Surg Eur 38(4): 439-440.

10. Isenberg JS, Nguyen H, Salomon J (1994) Bilateral simultaneous groin flaps in the salvage of a pediatric blast-injured hand. Ann Plast Surg 33(4): 415-417.

11. Hough M, Fenn C, Kay SP (2004) The use of free groin flaps in children. Plast Reconstr Surg 113(4): 1161-1166.

12. Buja Z, Arifi H, Hoxha E (2013) Repair of degloving fingers with abdominal tunnelization flap. J Hand Surg Eur 38(4): 439-440.

13. Lin W, Zheng T, Wang Q (2005) Study on the effect of pedicle skin flap of subdermal vascular plexus on repairing the hand injury. Zhongguo Xiu Fu Chong Jian Wai Ke Za Zhi 19 (7): 528-530.

14. Colson P, Houot R, Gangolphe M, de Mourgues A, Laurent J, et al. (1967) 
Use of thinned flaps (flapgrafts) in reparative hand surgery. Ann Chir Plast 12(4): 298-310.

This work is licensed under Creative Commons Attribution 4.0 License

DOI: $10.19080 / J O J O O S .2017 .01 .555555$
15. Ahmed A, Mahammed F, Khalid S (2007) Reconstruction of Hand and Forearm Defects by Abdominal Thin Skin Flaps. J Plast Reconstr Surg 31(2): 181-185.

\section{Your next submission with Juniper Publishers will reach you the below assets}

- Quality Editorial service

- Swift Peer Review

- Reprints availability

- E-prints Service

- Manuscript Podcast for convenient understanding

- Global attainment for your research

- Manuscript accessibility in different formats ( Pdf, E-pub, Full Text, Audio)

- Unceasing customer service

Track the below URL for one-step submission https://juniperpublishers.com/online-submission.php 